\title{
An Exploratory Study of Four Urban Community Libraries in Nampula City, Mozambique: Do They Satisfy Community Informational Needs?
}

\section{https://doi.org/10.1515/libri-2016-0111}

\begin{abstract}
This exploratory study describes the characteristics of four independent urban community libraries in Nampula city, located in northern Mozambique, East Africa. In a country where public library services are inadequately equipped to address the educational, informational and cultural needs of its citizens, the emergence of urban community libraries in the city indicates that the population is seeking better alternative sources of information. The study profiles four urban libraries to identify their role in the communities they serve and determine whether they conform to Mostert's (1998) community library model. A case-study design was used with data collection techniques of structured interviews to collect qualitative data from library directors and librarians, a multiple choice questionnaire to obtain user responses, while further statistical data was obtained from collection, circulation and library user records. Findings indicate these four urban libraries only minimally adhere to Mostert's model and are instead mimicking existing public and school libraries by catering to predominantly secondary and university level students. As a result, the educational, informational and cultural needs of other key groups in the community, such as the illiterate, neo-literate and disadvantaged, are ignored. This is due to a lack of trained library professionals and restrictive library policies.
\end{abstract}

Keywords: community libraries, urban libraries, community development, Mozambique

\section{Introduction}

How do city-dwellers in the East African Lusophone country of Mozambique satisfy their informational, educational and cultural needs when the number of public

*Corresponding author: Elizabeth Eva Szabo, Faculdade de Educação e Comunicacao, Catholic University of Mocambique, Nampula, Mozambique, E-mail: eebszabo@yahoo.co.uk Ilidia Vieira, Faculdade de Educação e Psicologia, Universidade Catolica, Porto, Porto, Portugal libraries in cities is limited, collections are small and limited in scope and staffed by librarians with only rudimentary training? The Public Library Manifesto, as defined by the United Nations Educational, Scientific and Cultural Organization (UNESCO), establishes the mission and role of public libraries, clarifying that a public library acts as "the local gateway to knowledge, provides a basic condition for lifelong learning, independent decision-making and cultural development of the individual and social groups" (UNESCO 1994, 1). Public libraries in Mozambique, however, are still struggling to fulfill the criteria of UNESCO's Public Library Manifesto, seen as Issak, in the most recent study on the country's libraries (2003, 10-12), argues for an overhaul of the Mozambican national public library system. Issak offers a list of constraints which can be summarized as follows:

\footnotetext{
a lack of professional training of librarians and lack of recognition of librarianship as a profession; no coordinating or regulatory bodies responsible for public libraries; absence of a conceptual framework which defines the role of public libraries; no national distribution system of books/materials; the lack of a legal framework that incorporates public libraries in the socio-economic development of the country, and lack of financial resources.
}

Further research on libraries in Mozambique is scarce but Issak's findings are generally substantiated in existing literature on the quality of services provided by subSaharan Africa's public libraries. A study by Rosenberg $(1993,1)$ of the public library system in Africa, with a specific focus on Kenya, indicates that public libraries in Africa, even after three decades of independence, are "generally in decay and disarray; they are placed low on the national lists of priorities and government funding is made grudgingly, if at all." A lack of understanding of the context in which public libraries in developing countries operate is identified as another cause of the decay of public libraries, alongside a lack of funding, meaning that it is less likely that a comprehensive analysis and identification of the public's information needs will be carried out by government bodies when public libraries feature low on the list of national priorities. According to Du Plessis (2008) public libraries in South Africa would 
serve users better if they functioned less as a "food silo of a uniform food stored with a restricted availability" and more as "a community kitchen where a variety of foods are offered to please the local palate." Mchombu (1991) observes a "decoupling from the key target groups" of the population and that public libraries in Africa tend to serve a minority of middle-class users who are already literary. Such disconnect is the result of the management of public libraries based on the Anglo-American model familiar only to the educated, colonial elite but regarded, in Mchombu's view, as an "alien institution" by the local population. The persistence of the image of a public library in Africa being an institution only for the educated remains strong, confirmed by Hart $(2012,43)$ in a two case-study report on public library services using outreach programs to ensure social inclusion in South Africa. Hart's study reveals how South Africa's National Council for Library and Information Services Transformation Charter of 2009 shows "less than 10\% of South Africans at present belong to public libraries, that they are unevenly distributed, that school learners account for $70 \%$ of their usage, and that $74 \%$ of public libraries lack Internet access.” Krolak $(2005,2)$ analyzes the evolving role of public libraries which underpins the creation of a "dynamic and stimulating literate environment at home, in the classroom, in the workplace and in the community" but it is highly concerning that Hart (2012, 43) indicates the South African population's view of public libraries to be that of "an irrelevant collection of books for the educated, the middle class and students." The public library system of Mozambique may be in an even weaker state than public libraries in neighboring countries such as South Africa when taking into account that the country is currently ranked $185^{\text {th }}$ in the world according to the 2013 Human Development Report of the United Nations Development Program (UNDP 2013, 143), whereas South Africa ranks $121^{\text {th }}$.

Nevertheless, the general public's perception of its need for libraries as a means of access to information has been manifested in Mozambique, as in other sub-Saharan countries, by the emergence of community libraries. There have been various interpretations as to what differentiates a community library from a public library: Stilwell (1989) identifies the birth of the former as having taken place in the United Kingdom (UK) and United States of America (USA) in the 1970s. The practice of providing citizen and survival information via government-sponsored entities such as the Citizens' Advice Bureau in the UK and the Veterans' Advice Bureau in the USA was the springboard for the creation of community information centers within public libraries themselves. In the 1970s public libraries in both countries were subjected to criticism that their services catered predominantly to middle-class users: by expanding traditional services to include provision of citizen and survival information via community information centers public libraries could reposition themselves as more relevant to disadvantaged members of the population who had previously ignored public libraries as a possible source of information and advice on legal, political and health matters. According to Stilwell citing Bunch (1987, 7), public libraries were perceived as an appropriate mechanism for providing such information on a wider scale due to their established geographical distribution and ostensibly 'neutral' stance. In developed countries such as the USA the community library model has been adopted, an example being a Chicago public library which operates with a focus on community-building as described in the study conducted by Kretzmann and Rans $(2005$, 6). In the UK a community library can be interpreted as a public branch library which has been given over to the partial or total management of a local community, (Arts Council, 2013, 1). In this case the term community is related to who is responsible for governance of the library.

The adoption of the concept of community libraries in developing countries such as South Africa had been recommended as a more effective strategy for tackling issues of illiteracy and unemployment faced by the disadvantaged and marginalized members of the population (Nassimbeni 1990). However, despite this recommendation, public libraries remained mostly resistant to the adoption of the community library model, although by 2007 there have been exceptions, such as the creation of

\footnotetext{
various services in conjunction with other partners to empower communities, especially the so-called "corners", such as the Library Business Corners in the Western Cape.[...]. Similarly, in the Free State, Government Information Services Corners, Community Information Services Corners, Business Information Services Corners, and Literacy Corners (containing repackaged information for neo-literates and adult basic education and training practitioners) are developed and tailor-made for libraries by the provincial head office (Witbooi 2007, 69).
}

One of the obstacles to the adoption of the community library model was public libraries' perception of what constituted community information. The purpose of community information is to serve as "information that is in essence survival information, needed for participation as a full and equal member of society" (Stilwell 1991, 19), which firstly must be identified by the community being served through the process of information needs 
assessment, "The pattern of library services need to be approached the bottom upwards rather than the top downwards" (Stilwell 1991, 22).

Eventually, in response to the continuing reluctance of public libraries to a whole-scale implementation of the community library model, voluntary associations in South Africa during the 1980s and 1990s founded their own resource centers. Stilwell (1992) describes the formation of resource center forums whose purpose was "to empower communities through the provision of resources and facilities otherwise unavailable to the oppressed communities". One of the characteristics of resource centers was that they were often created by a group of citizens with a common aim, such as to exchange ideas and experiences related to their work, preserve information in documentary form or provide educational resources to students, all through a democratic and participative management approach. In two later studies, Stilwell (1994; 1997) identified a further characteristic of non-governmental community libraries or resource centers in South Africa, their oppositional nature to the existing political regime where access to information was concerned. However, the role of such libraries and centers has been brought into question since the dismantling of the apartheid system and advent of a democratic government. The wide-scale adoption of the community library model by public libraries in South Africa remains in doubt as there is still "limited evidence of the principles and practices of community librarianship" (Stilwell 1997, 27) in the public library sector.

By contrast, the community library model has been adopted in other African states such as Kenya not so much as an overtly political gesture to protect the practice of democracy in the face of an oppressive regime, but more as a means of promoting sustainable socio-economic development, such as in rural areas. Such rural community libraries are funded to a certain degree and managed by the rural community itself, as described in Dent and Yannota's two studies of the Kitengesa Community library in Uganda (Dent and Yannota 2005; Dent 2013). These studies indicate that a library with such a role in a rural area can successfully support development among various groups in the community, such as children, the illiterate, neo-literate and economically disadvantaged.

Meanwhile, in urban areas, studies emerging from Brazil, another ex-Portuguese colony, indicate attempts to establish independent urban community libraries in cities surrounded by highly populated slum areas. Machado (2009) defines the concept of a "new type of library in Brazilian society" as a community library which "is a result of a cultural act and which is created by the community not for the community [...] and which is 'organized according to the principles of autonomy, flexibility and local network"'. Santos, Senna and Miranda (2010, 33), in a study of the Escritor Lima Barreto Community Library in Mare, Rio de Janeiro, suggest that the purpose of a community library is not just to hold an information and education role but also to "create a cultural dialogue with a community, democratize access to information, facilitate studying, support the culture of reading, provide citizens with equal access to digital resources and thereby reduce socio-economic differences”. Cavalcante and Feitosa $(2011,124)$ in a study on community libraries in the Ceará municipality, also in Rio de Janeiro, analyze the role of a community library in urban areas with no public community library provision. Their findings describe the poor-rich information divide which exists in Brazilian cities, where "on the one hand, there are citizens who in the informational and communication context are technologically well-served and on the other hand, citizens who live in poverty, suffer social and educational inequalities and demonstrate a low-literacy rate". Oliveira, Vicente, Marcelino and Silva (2010, 100) report on the Saramenha urban community library in the Ouro Preto district of the Minais Gerais municipality, asserting that the library functions as a "point of social convergence" and also "supports and promotes educational and cultural activities".

The above studies of Kenyan rural community libraries and Brazilian urban community libraries indicate varying degrees of conscious adherence to the social purposes of Mostert's community library model and its characteristics embodied in a three-fold approach that may be summarized as a) providing information matching the specific needs of the community, b) stimulating local development and socio-cultural transformation and c) serving as a locus for information and cultural activities (Mostert 1998). The Brazilian studies are particularly significant as they indicate the emergence of small urban community libraries, created either via cooperation with non-governmental organizations or by communities themselves, in cities possessing large areas of slumdwellings, a characteristic of urban settlements shared by both Brazil and Mozambique (United Nations Habitat, 2012, 3). The Mozambican government's report, 'Cities without slums' confirms that "Many residential areas in the urban centers of Mozambique have typical slum characteristics: low-incomes, no basic urbanization, [i. e. an absence of urban infrastructure], high population density, poor environmental conditions, poor building quality, absence of an urban culture" (2007, 6). 
Mozambique is linguistically isolated from Anglophone African countries and as a result Mozambican librarianship may be unaware of alternative library models that have been adopted in surrounding sub-Saharan or other developing countries. On the other hand, Brazil and Mozambique share a history of Portuguese colonial oppression, a common official language, cultural and economic links and demonstrate comparable socioeconomic characteristics in terms of the living conditions of the majority of their city populations. It therefore merits speculation of whether urban communities in Mozambique have followed Brazil's lead in approaching an adoption of Mostert's community library model and its characteristic social purpose ideology as an alternative to the Western model public library system.

Basic statistical evidence exists as to the nature, size, mission and objectives of community libraries, rural or urban, in Mozambique, (Fundo Bibliográfico De Língua Portuguesa 2003). However no research has yet been carried out in Mozambique, as has been the case in Brazil, to specifically ascertain how urban community libraries in the country are established and to what degree they compensate for the lack of public libraries and satisfy their users' informational, educational and cultural needs. A small-scale exploratory study which focused on a group of four urban community libraries in Nampula, the second largest city in Mozambique, was therefore undertaken to determine how these libraries perceive their role in the community and serve their users. The specific objectives of the research were:

1. To construct from the international literature a conceptual framework that defines independent urban community libraries;

2. To draw up a profile of four community libraries in Nampula city, Mozambique to discover how they serve users' needs, how users view the services of these libraries and determine the impact of these libraries on the communities in which they operate;

3. To ascertain to what extent these four independent urban community libraries in Nampula city conform to or diverge from the profile of a true community library as defined by Mostert (1998).

\section{Historical Background}

The East African Lusophone country of Mozambique, surrounded by Tanzania, Malawi, Zambia, Zimbabwe, Swaziland and South Africa, emerged from 500 years of Portuguese colonial rule in 1975. Independence was followed by a long-standing and highly destructive civil war which finally ended in 1992, since which Mozambique has been undergoing large scale rebuilding of its economic, physical and social infrastructures (Chilundo 2006). In 1975 the national illiteracy rate of a population of 10.62 million was $93 \%$ (World Bank 2015) but this had fallen to $60 \%$ by 2000 (Issak 2003, 31), while a nationwide survey of archives, libraries, and information centers in Mozambique conducted by the Fundo Bibliográfico de Língua Portuguesa (FBLP) revealed that in 2003, with a population of 19.87 million (World Bank 2015), only 261 units serving as public libraries, archives or information centers existed in the entire country (FBLP 2003, 13). The 2003 survey indicated the presence of only one city public library with 5,000 items in Nampula city while six smaller branch libraries with collections of approximately up to 1,000 items were located outside the city, distributed around the Nampula province. Figures for the city's current population, now at 380,297 inhabitants, (Portal do Governo da Provincia de Nampula 2015), indicates that access to information via public libraries is still insufficient, despite the opening of a newly constructed city center main public library with 10,000 items in 2010. The four urban community libraries could capitalize on such insufficient resources, with aim of this study to evaluate how well they realize their potential for satisfying the city population's informational, educational, and cultural needs.

\section{Conceptual Framework}

Studies undertaken by Cavalcante and Feitosa (2011), Oliveira, Vicente, Marcelino and Silva (2005), and Da Costa Santos, Senna, and Miranda (2010) are evidence of the ideological acceptance of the community library model, namely what these libraries aimed to achieve that would socio-economically benefit disadvantaged members of a community. However Mostert's (1998) study was considered a more appropriate basis for a conceptual framework in this research as it specifically defines the range of norms, i. e. the specific identifying characteristics, by which such a library may be differentiated from a government-funded public library: establishment, governance, finance, aims, users, service attitudes, services, types of media and cooperation with other organizations. In summary, according to Mostert's norms, a true community library is created in an existing building, then financed in full or part and governed by members or sponsors of a given community, while users can be restricted to those who, for example, pay a subscription fee. The information provided by the library connects 
directly to the day-to-day lives of the users, including the disadvantaged in a given community, consisting of "survival information" and "citizen's action information". Such information may be not only in traditional book format but also more ephemeral form such as "pamphlets, brochures and newspaper clippings and oral information". The role of librarians is an active one engaging in the four activities of "information and referral, face-toface contact with the user to solve the user's problem, involvement by library staff in community activities and services", while working towards helping users becoming self-reliant. Library staff are drawn from the community which promotes trust amongst users and are able to communicate appropriately with all who use the services. Cooperation is a tool to be used for strengthening links with other organizations in the area involved in community development.

\section{Methodology}

A bounded case-study approach was used as the aim of the research was to "describe meaning, investigate processes and gain insight and in-depth understanding of an individual, group or situation", as defined by Lodico, Spaulding and Voegtle (2006, 269), a method which "allows for the collection of detailed information using a variety of data collection procedures" (Creswell, 12). A group of four independent, i. e. non-government funded, urban community libraries in the northern city of Nampula, Mozambique, was selected to obtain perceptions of their own role and characterize their response to the situation of government funded public library provision in relation to users' library needs. A case study approach was considered appropriate as it provides "a detailed (thick) description of the situation, and captures the complexity and uniqueness of the case information," (Lodico, Spaulding and Voegtle 2006, 270). The case study was bounded so all participants in the study were associated directly with one of the four selected community libraries, i.e. the director and librarians of each library as well as registered users. The study was also bounded geographically, with only independent urban community libraries that existed within the six city districts of Nampula selected for study.

\section{Participants}

Libraries operating in Nampula city can be identified by consulting the publication 'Directory of archives, libraries and information centers in Mozambique' (Fundo Bibliográfico de Lingua Portuguesa 2003). The directory indicates there is a provincial public library with approximately 5,000 items and nine other government-funded public libraries in the city. Three of these function as district or administrative division public libraries and the remaining six as libraries of government teacher training schools and a military academy. However the only edition of the 'Directory' available to the researcher was published in 2003 and therefore could not provide any information on independent, non-government funded community libraries established since that date. Nampula city consists of six administrative posts similar to municipal 'arrondissementes' or divisions: 1) Central, or the city center zone, surrounded by 2) Muhala, 3) Muatala, 4) Natikiri, 5) Napipine and 6) Namikopo, with each of these divisions having two or more 'bairros' or suburbs. The snowball method (Walliman 2005, 279) was used to ascertain the existence of any community libraries set up since 2003, with potential participants representing a secret or, in this case, not well-known group or society of libraries discovered by the researcher via introduction through one of the group's members.

The first contact with one of library group was made in 2013 when the Centro Santa Cruz Community Library approached the researcher's institution, the Catholic University of Mozambique, with a request for practical training for their staff on a computerized library management system. After training had been completed the director of the Centro Santa Cruz Community Library was offered and accepted an invitation to participate in the study. The director identified four other independent community libraries within the city center who were formally approached, with three agreeing to participate in the study. The initial objective of the study was to involve at least one library from each of the six districts but only three districts indicated the existence of independent urban community libraries. These were:

(a) The Centro Santa Cruz Library in the Muahivire bairro of Muhala

(b) The Sisters of the Presentation of Maria Order Library in the Namutequeliua bairro of Muhala

(c) The Naiwanana Library in the Central zone

(d) The Sao Joao de Deus Development Center Library in the Mutauanha bairro of Muatala.

The remaining fifth independent community library, located nearby the Pedagogic University in the Napipine division, was not included as authorization to participate was not obtained from the library director before research was concluded. However, the participant libraries were 
all situated in bairros that had characteristics of inner city slums with a heterogeneous population, as defined by Cavalcante and Feitosa (2011) in terms of levels of education, literacy, socio-economic status, employment prospects and access to information technology.

\section{Data Collection}

The following data collection techniques were used:

(a) Semi-structured interviews with the director of each library to ascertain its history, mission and objectives.

(b) Semi-structured interviews with library staff to record

(i) qualitative data, i.e. their experiences, attitudes and opinions of the effectiveness of their community library;

(ii) quantitative data, i.e. the size and character of each collection, number of readers registered and using the library's resources

(c) A brief questionnaire administered to a number of each library's users to obtain:

(i) demographic data about library users (i.e. age, gender, level of education, occupation and/or profession),

(ii) a series of multiple choice questions derived from the literature to ascertain types of information users requested and how often they used the library,

(iii) an open question to elicit comments on what kind of additional services users would like the library to provide to users

(d) Statistical data obtained from circulation records and the number of user registrations kept in each library

All library directors and librarians at the four selected sites agreed to participate in the study thereby providing $100 \%$ returns. Copies of the library user questionnaire were distributed by the researcher over a period of one week in July 2014, a period longer than initially planned as the researcher was informed upon arrival at the selected libraries that, according to the librarians, there was not a high number of library users during that month as it was the school/university holiday period. Library users were invited to participate voluntarily in completing copies of the questionnaire, which were completed face to face with the researcher due to fewer users present than anticipated and users' lack of experience in completing a self-administered questionnaire. The face-to-face approach also allowed the researcher to focus in more depth on each user who, in turn, was able to orally express in greater detail their motivations for visiting the library and opinions on the quality and range of the library's services. A total of 45 users completed the questionnaire, 15 from the Sao Joao de Deus Development Center Library, 14 from the Centro Santa Cruz Library, 9 from the Sisters of the Presentation of Maria Order Library and 7 from the Naiwanana Library.

\section{Data Analysis}

Collected data were divided into three groups prior to analysis, namely the library directors from each of the four sites, librarians from each site and the total number of library users who had participated at each site. This separation was deemed appropriate as the library directors were in a position to provide information about their libraries from a global and strategic point of view in relation to all of Mostert's nine norms, establishment, governance, finance, aims, users, information, services, staff and cooperation. The librarians, on the other hand, represented a source of information which focused more specifically on the norms of governance, users, information, services and cooperation from the point of view of providers who had direct day-to-day contact with users. Finally, as the end-users, library patrons were considered an appropriate source of information with regards to the norms of information, services and staff by virtue of their position as recipients.

During analysis two clustered summary tables (Miles and Huberman 1994, 180-182) were created based on units of data obtained from the group of library directors and librarians. The summary table for each group consists of three columns, the first of which contains the predefined codes derived from some or all of Mostert's nine norms depending on which group's responses were analyzed. The second column contains indicators which identify thematic constructs that emerged from the analysis, while the third column contains units of data extracted from the interviews and questionnaire. The indicators that emerged revealed to what extent the libraries were or were not adhering to Mostert's nine norms of a true community library. Quantitative data consisting of demographic data and individual responses to multiple-choice questions in the library users' questionnaires were analyzed and presented in tables or charts. Statistical data from circulation and user registration records were analyzed and displayed in chart format. 


\section{Findings}

The results of data analysis were organized and presented in accordance with Mostert's (1998) nine norms that define a community library. Data gathered for each norm were interpreted and used to construct a profile (Table 1, Mostert's nine norms and indicators) of the four libraries in terms of how they served their users and their impact on their communities. The profiles were then evaluated to ascertain how closely the characteristics of the four libraries conformed to or diverged from Mostert's model.

\section{Evaluation}

\section{Establishment}

The Centro Santa Cruz, Presentation of Maria, and Sao Joao de Deus libraries all function as components of community centers established by three separate religious orders of nuns working in Nampula city. The Naiwanana library, however, was set up by a group of Mozambican citizens themselves, a Mozambican student association which recognized the need to address the difficulties secondary school students experienced in accessing educational material. The other three libraries were established following suggestions/initiatives from aid volunteers from Europe working in Nampula with the orders of nuns, rather than direct requests from the community. The religious organizations have been operating in Nampula city for a number of years and all reside within the bairros close to the community: they could, arguably, be considered members of the community but enjoying the benefits of greater social influence as well as better education and access to funding that most members of the community do not experience. A few members of the community were involved in the physical organization of the libraries during set up and were appointed as librarians after receiving basic training in library

Table 1: Mostert's 9 norms and indicators derived from interviews with library directors and librarians.

\begin{tabular}{|c|c|c|}
\hline $\begin{array}{l}\text { Mostert's } 9 \text { norms of } \\
\text { a true community } \\
\text { library }\end{array}$ & Indicators derived from interviews with Library Directors & Indicators derived from interviews with librarians \\
\hline Establishment & $\begin{array}{l}\text { 1. Library set up by external agents } \\
\text { 2. Library set up by a student association }\end{array}$ & $\mathrm{N} / \mathrm{A}$ \\
\hline Governance & $\begin{array}{l}\text { 1. Governance by library directors } \\
\text { 2. Governance by student association and community members }\end{array}$ & $\begin{array}{l}\text { 1. No participation } \\
\text { 2. Active participation }\end{array}$ \\
\hline Finances & $\begin{array}{l}\text { 1. Library is part of a centre with external funding } \\
\text { 2. Library is financed by internal revenues }\end{array}$ & $\mathrm{N} / \mathrm{A}$ \\
\hline Aims & $\begin{array}{l}\text { 1. Provide materials for school and university students } \\
\text { 2. Provide childcare facilities, } \\
\text { 3. Raise literacy levels }\end{array}$ & $\mathrm{N} / \mathrm{A}$ \\
\hline Users & $\begin{array}{l}\text { 1. Restricted with subscription fees } \\
\text { 2. Unrestricted no subscription fees }\end{array}$ & $\begin{array}{l}\text { 1. Secondary and university student } \\
\text { 2. Pre-school children }\end{array}$ \\
\hline Information & 1. Print media & $\mathrm{N} / \mathrm{A}$ \\
\hline Services & $\begin{array}{l}\text { 1. Educational material } \\
\text { 2. Reading culture, } \\
\text { 3. Legal information, } \\
\text { 4. Daily problem-solving, } \\
\text { 5. IT training, } \\
\text { 6. Access to the Internet }\end{array}$ & $\begin{array}{l}\text { 1. Education } \\
\text { 2. Recreation } \\
\text { 3. Culture } \\
\text { 4. Health information } \\
\text { 5. Legal information } \\
\text { 6. IT literacy, } \\
\text { 7. Visibility of services } \\
\text { 8. Childcare } \\
\text { 9. Language barriers }\end{array}$ \\
\hline Staff & 1. Passive attitude & $\begin{array}{l}\text { 1. Restricted active participation in identifying } \\
\text { users' needs } \\
\text { 2. Desire for training }\end{array}$ \\
\hline Cooperation & 1. External partnerships & $\begin{array}{l}\text { 1. Cooperation as opportunity for training } \\
\text { 2. Opportunity for exchange of knowledge and } \\
\text { librarianship skills. }\end{array}$ \\
\hline
\end{tabular}


organization also provided by volunteers from Portugal. The manner in which these three libraries were established diverges somewhat from Machado's (2009) observation that "a community library is set up by the community rather than for the community" whereas the Naiwanana library adheres to Mostert's norm of the true community library as the community or at least one of its section, a Mozambican student association, participated fully in its creation.

\section{Governance}

The three libraries established by the religious organizations all show signs of adhering to an autocratic managerial model. Each has a director who assumes most of the managerial responsibility, principally procurement of funding and donations of books for the library and policy-making, whilst librarians are paid full-time or parttime employees who appear to have little opportunity to participate in decision-making on library policy or operations. The Naiwanana library, on the other hand, is managed by a student association library council or committee which includes librarians, library users, teachers from the community and interested members of the public, meaning that it is therefore potentially better positioned to identify and provide relevant services to its users. It also adheres more than the other three libraries to the "democratically-based library and information work models" (Stilwell 1994, 304).

\section{Finance}

All four libraries depend on funding from various sources but not from the government. The three libraries run by the religious orders obtain external funding or donations of books by maintaining contacts with private individuals, philanthropic organizations and publishers in Portugal. In addition, one of these libraries receives internal funding via a budget allocation from the operating costs of its mother organization. The Naiwanana library receives internal funding from the students' association obtained from rents received from the association's student housing. Some books in its collection are bought by the library itself while some come from donations arranged by members of the council. The libraries run by the religious order obtain some funds directly from the community, i. e. library users, by means of annual subscription fees which partially supplement the operating costs. In this respect, the libraries adhere to Mostert's norm regarding finance by funding their operations through a combination of contributions from both community and private sponsors.

\section{Aims}

Mostert defines the aims of a community library as providing a "pro-active service" which "empowers the disadvantaged" and "makes all community resources available to all community members" $(1998,76)$. Of the four libraries, the Centro Santa Cruz and the Presentation of Maria libraries evidenced the most efforts in this respect: although their libraries focus heavily on providing educational materials to students and little on provision of other library resources for community members who are not students, great efforts have been made to provide childcare facilities for parents in the community. These two libraries have been pro-active in this regard by creating crèches which accommodate up to 150 preschool children a day, with the Centro Santa Cruz library in particular investing in staff training of one of the librarians who is to be trained as an Infant Educator. This librarian gives lessons in basic reading and arithmetic to the children, thereby establishing the beginnings of literacy and numeracy learning. Local musicians and artisans from the community are contracted to provide music, dancing as well as arts and crafts activities to enable the development of children's cultural expression, while the Centro Santa Cruz has shown an awareness and sensitivity to language barriers that exist in Mozambique by providing extra 'Explanation lessons' to children attending primary school who may speak a local African language (Macua) at home but receive lessons at school in the official Portuguese language which often poses as an impediment to learning. However, it was notable that none of the libraries allowed the borrowing of books to read at home even though the promotion of reading in any locale beyond the library would have helped in the creation of a culture of sustained reading in the official Portuguese language, not only for study but also pleasure as proposed by Krolak's (2005, 2) theory of the importance of a "dynamic and stimulating literate environment”. Of all four libraries, Centro Santa Cruz illustrated more features of Mostert's (1998) definition of a community library which attempts to "empower disadvantaged members of the community", while also conforming in some respects to Du Plessis' (2008) analogy "of a library being like a community kitchen that offers a variety of foods". The Presentation of Maria library also provides a crèche, heavily oversubscribed 
by parents in the library's community but where less managed learning of pre-school children occurs: unlike the Centro Santa Cruz library it does not have a separate reading room or sufficient quantity of books for preschool and primary-school children. All four libraries initially aimed to support literacy through Adult Education, reflecting Witbooi's (2007) study of the use of outreach programs provided by community libraries in the form of "Literacy Corners" however, owing to disorganization in the provision and payment of government Literacy Trainers, a weakness recognized by the government in a recent publication on strategies for reducing illiteracy in Mozambique, (República de Mocambique 2007 , p. 11), the four libraries were unable to maintain provision of literacy training. Information communication technology, (ICT) training, however, is an established feature of all the four libraries which indicates their recognition of the importance of knowledge of and selfreliance in the use of ICT for community members. All libraries provide some form of ICT training in separate computer rooms and access to the internet while the presence of computers in the libraries also aims to reach out to those members of the community who otherwise would have little access to the Internet.

\section{Users}

According to user registration records consulted at each of the four libraries, the number of registered users ranges from 350 to 2,000. The Naiwanana library has the largest number of registered readers, $(2,000)$ but librarians here indicate that not many of these are repeat users (Table 2, Collection Size, Registered Users, Circulation and Seating). The Naiwanana library is the only library of the four studied located in the city center, on the third floor of an apartment building with seating for only ten users. The limited number of repeat users could be due to location as it is further from the bairros than the other three libraries and would involve transport costs to visit. The St. Joao de Deus library has the largest collection of the four libraries and largest seating capacity, but is less frequently visited than the Centro Santa Cruz library. The Centro Santa Cruz has the largest circulation number of all four libraries, suggesting that factors such as collection quality and other service types such as internet access, rather than collection size or subscription charges, are the criteria by which users select which library to frequent (Figure 1, Users' reasons for visiting library).

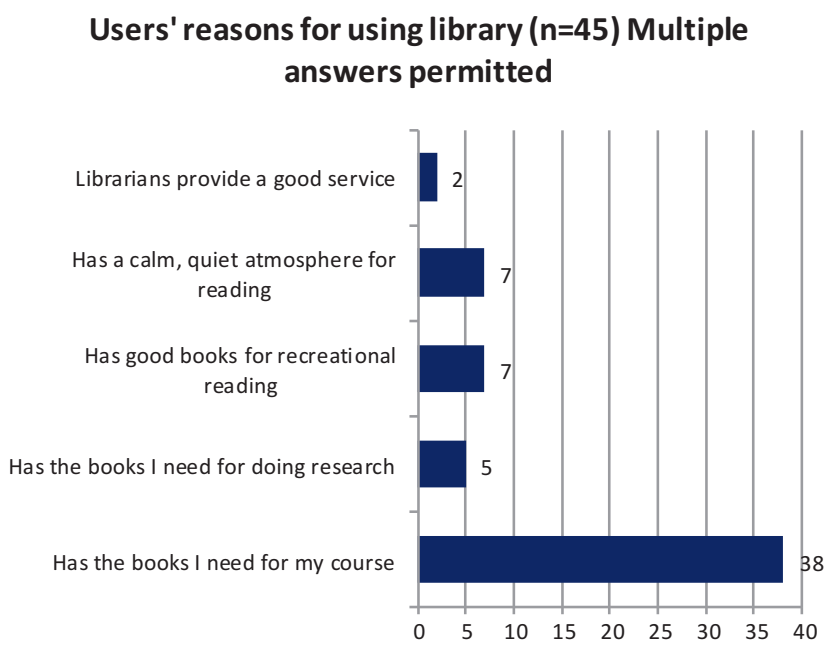

Figure 1: Users' reasons for using the library.

Three of the libraries welcome all members of the community but charge subscription fees ranging between 60-100 meticais (USD\$2-\$3) per annum. While this value may not appear to be high by developed country standards, the minimum monthly wage in Mozambique for persons with the lowest level of education is

Table 2: Collection size, circulation and seating by library.

\begin{tabular}{lccrr}
\hline Library site & $\begin{array}{r}\text { Collection } \\
\text { size }\end{array}$ & $\begin{array}{r}\text { No. registered library } \\
\text { users }\end{array}$ & $\begin{array}{r}\text { Circulation } \\
\text { (September } \\
\text { 2013)* }\end{array}$ & Seating capacity \\
\hline Centro Santa Cruz - Muahivire/Muhala & $3,000+$ & 622 & 1123 & $\begin{array}{r}20 \text { Adult Rreading Room } \\
\text { 20 Fiction/Young Readers Reading } \\
\text { Room } \\
50\end{array}$ \\
$\begin{array}{l}\text { Presentation of Maria - Namutequeliua/ } \\
\quad \text { Muhala }\end{array}$ & 2,500 & $350+$ & 805 & 70 \\
$\begin{array}{l}\text { St Joao de Deus - Mutauana/Muatala } \\
\text { Naiwanana - City centre }\end{array}$ & 3,880 & $400+$ & 520 & 10 \\
\hline
\end{tabular}

* The month of September was selected as one of the period of highest circulation in the libraries, being the beginning of the third semester of the secondary school and close to the beginning of the second semester of the university academic year in Mozambique. 
approximately 3,500 meticais or USD \$83 (Hanlon 2013), which restricts the number of community members who can enjoy library resources. The directors of these three libraries argue that charging for services pre-selects those who are serious library users, an attitude which differs from the traditional European public library model whereby all members of the community have free access. These three libraries do not allow entry of any community members who wish to use the library as a refuge or place to safeguard and occupy children after school hours which occurs in public libraries in developed countries. The Naiwanana library, on the other hand, has a more relaxed entrance policy and does not charge for services on the grounds that not all users have economic means to pay a subscription charge. Whilst a more liberal and democratic stance, it reduces the opportunity of generating a small level of income for purchasing resources for the library.

In terms of user target groups, both library directors and librarians indicated their principal user target group was students from secondary schools and university students, within the age range of 15-29 years, confirmed by the statistical data (Table 3, Age range and Figure 2, Occupation of users) "that is the main type of user here". All librarians indicated that libraries contained material for recreational reading, i.e. fiction for all age groups, but that "there are not many" in that user group, corroborated via the questionnaire data (Figure 3, How users spend time in the library). Users made much use of the library with 31 of the 45 respondents visiting the library two or more times per week, (Figure 4, Frequency of use), while user questionnaire responses confirm there are few readers in the 14 or under age group or over 30 years age group (Table 3, Age range) The library director of the Centro Santa Cruz library expressed frustration with the challenge of creating a reading culture despite having a relatively well-stocked fiction reading room. The policy used for encouraging

Table 3: Age range and gender of library users.

\begin{tabular}{lrrr}
\hline Age range of users & Male & Female & Total \\
\hline $13-14$ yrs & 0 & 1 & 1 \\
$15-19$ yrs & 14 & 6 & 20 \\
$20-24$ yrs & 14 & 2 & 16 \\
$25-29$ yrs & 4 & 1 & 5 \\
$30-34$ yrs & 1 & 0 & 1 \\
$35-39$ yrs & 0 & 0 & 0 \\
$40-44$ yrs & 1 & 0 & 1 \\
$45+$ yrs & 1 & 0 & 1 \\
Total & 35 & 10 & 45 \\
\hline
\end{tabular}

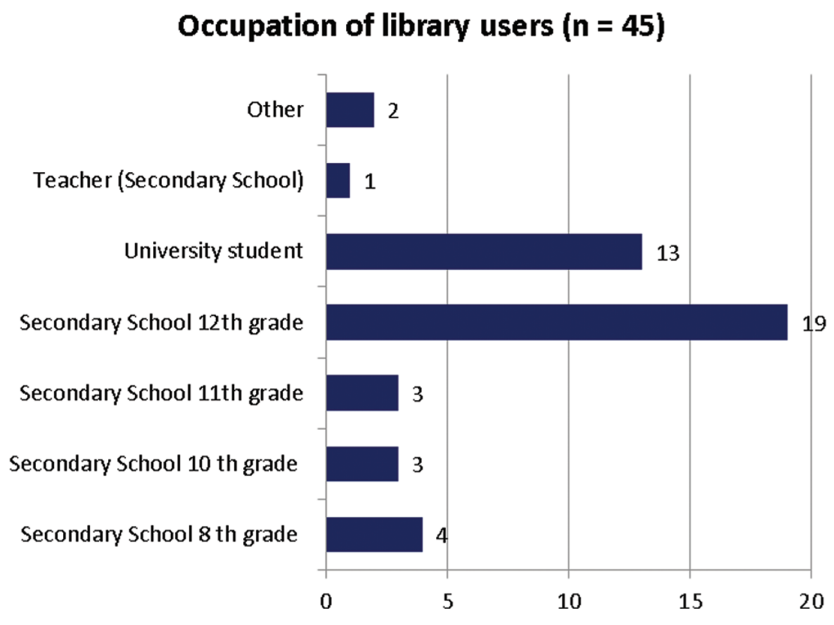

Figure 2: Occupation of library users.

recreational reading and thereby strengthening literacy among young readers and neo-literates was based on a reward system, i.e. users of the fiction reading room could "win" a free computer-training course or access to the adult educational reading room if they spent a certain number of hours in the fiction reading room. All librarians indicated the majority of users were school or university students and the number of adult readers for noneducational material was almost zero. The lack of an adult non-student user group was attributed to a lack of "a culture of reading, and the fact that the library's operating hours don't correspond with people's working hours, you know, after work, they are too tired to come to the library". Another impediment identified by librarians at the Naiwanana library was the language barrier, "many older people don't speak or read Portuguese very well and we have only books in Portuguese here", indicating the libraries were unable to provide an adequate service to non-Portuguese speaking users in the community. However, data from the user questionnaire revealed that directors and librarians were fully aware of the identity of their predominant users but their perception of the kinds of information their users were seeking did not wholly correspond with users' self-identified needs. Users' responses revealed that while textbooks for examination preparation were given the highest priority in terms of demand, the next priority was having access to reading material relating to practical concerns such as agriculture, health, legal issues and research skills (Figure 3, How users spend time in the library). Users' responses also indicated an interest in expanding their role from readers of textbooks to learners of new skills (Table 4, Additional resources or services that users would like the library to provide). 


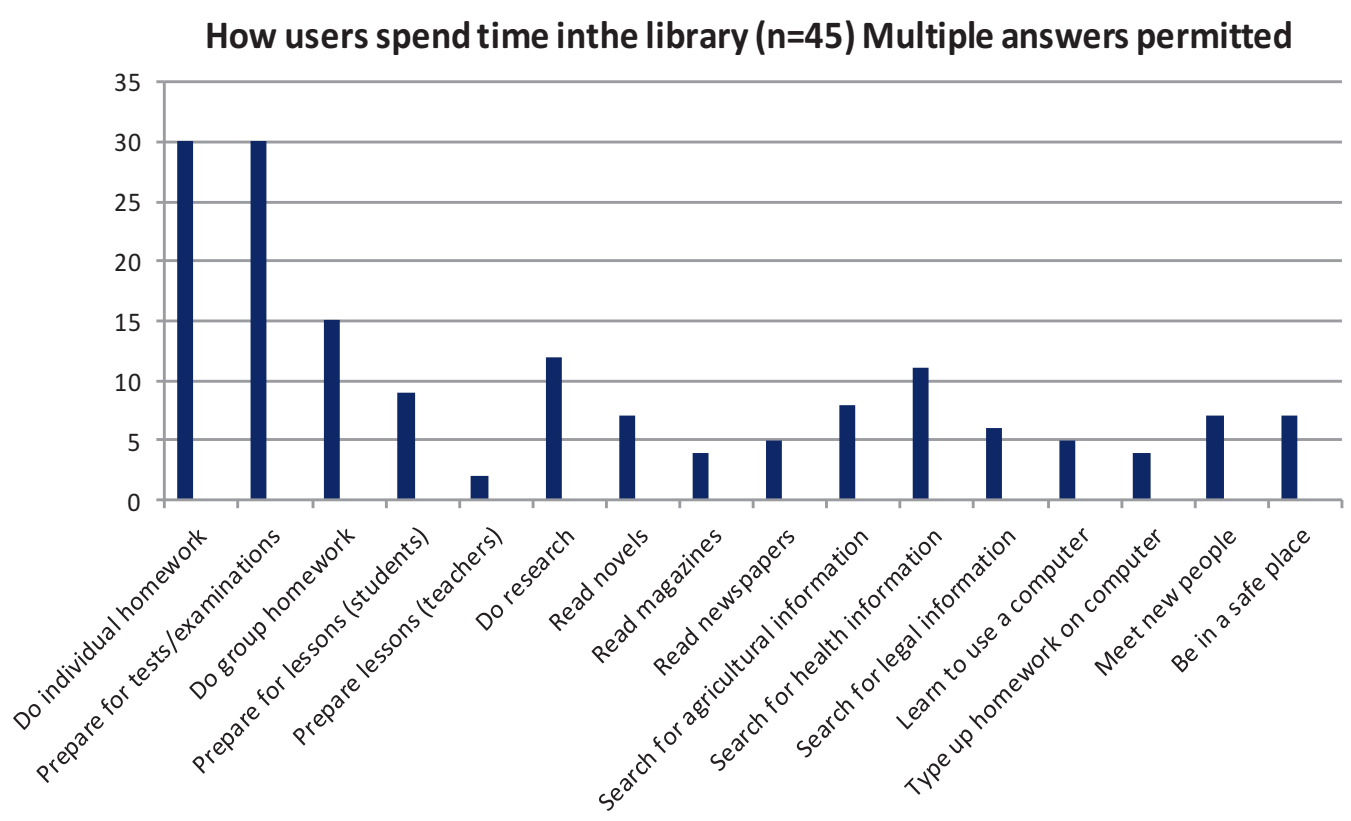

Figure 3: How users spend time in the library.

Table 4: Additional resources or services that users would like the library to provide.

\section{Physical resources}

Photocopier (6)

More seats (1)

Air conditioner (1)

Better equipped IT room (2)

Space for group work (1)

Space for practical work or experiments (1)

\section{Skills training}

How to do research (1)

How to read better (1)

Artistic activities (1)

IT courses (1)

\section{Reading resources}

More books for school subjects (6)

More books for university

subjects/courses (10)

Books on sport and arts (1)

Books that are not academic (1)

Newspapers (1)

Group activities

Reading group or club (1)

Study group for languages and arts (1)
Electronic resources

Access to the Internet for doing research (6) 
facilities, which can be viewed as a method of helping working parents, neither these nor the other two libraries provide any printed information beyond what is educational and recreational reading material. This is not entirely due to a lack of interest or policy on their part: unlike the libraries in Witbooi's (2007) study which have set up "Library Business Corners, Community Information Services Corners, and Literacy Corners" to empower members of the community, libraries in Mozambique are simply not able to acquire such information as it rarely exists in written form. Although no research has been undertaken to assess what measures are taken by Mozambican government bodies, hospitals, or legal entities to communicate their services to the general public in printed media, the researchers' experience and observation of public information dissemination in Mozambique is that few of these entities publish information in written form or in sufficient quantity to be distributed in libraries or information centers in the country. The preferred mode of communication for public information is predominantly via radio or television on the grounds that information in this form has a greater probability of reaching illiterate members of the community successfully. The lack of "survival information" and "citizen action information" is evident in all of the four libraries studied, as librarians in all four of the libraries stated that only educational information is demanded by users: "they only want books, textbooks, for studying, for passing examinations”. In contrast, however, to the librarians' perceived needs of their users, the results of the library user questionnaire revealed users were interested in accessing not only educational but also physical, electronic and skillsoriented resources (Table 3, Additional resources).

The librarians also indicated a lack of knowledge on how they could source survival and citizen action material from an entity that produced it, such as a legal aid center or health information center. Librarians suggested that users could, for example, consult an "encyclopedia for health" for health issues, a Civil Code for legal issues, (material which is more appropriate for lawyers and jurists) and textbooks on economics for users interested in setting up a small business. The collections in all of the libraries, ranging from 2,500 to 3,880 items (Figure 4, Collection size), consisted predominantly of educational textbooks and small amounts of fiction or recreational reading material. In this respect, all of the libraries conformed more to a school library rather than public library model. The four libraries effectively ignored the survival and citizen action information needs of the community and in this respect are still a long way from Santos et al's
(2010) study on community libraries acting as "agents of socio-cultural change”.

\section{Services}

Mostert (1998) defines the Services norm as an "active interaction between librarians and users". This interaction can take four forms: (a) librarians providing a referral service to users, (b) a direct service based on face-toface contact between librarian and user, (c) a back-up service in which librarians are actively involved in community activities and services that can aid users to solve their problems and d) a self-help focus that enables users to become self-reliant.

In terms of referral services, none of the libraries evidenced a clear policy or strategy for providing community information or the practice of referring users to sources of community information. Only one form of practical assistance was offered, helping parents complete forms to obtain the national Identification document obligatory for children who wish to progress to $11^{\text {th }}$ or $12^{\text {th }}$ grade education in secondary school. None of the libraries engaged in the practice of disseminating community information, as librarians indicated that only information about the library itself was communicated to users, e. g. opening hours and the arrival of new books, by means such as putting "a notice on the wall outside the library" or "the users telling each other". The principal service offered by librarians in all four libraries was that of direct face-to-face interaction to assist users in locating books in the libraries. Apart from the Centro Santa Cruz that has a librarian also working as an Infant Educator, which could be considered as an initial step towards engagement in a community service, namely crèche facilities, none of the other libraries provided such a problem-solving service, while the service of enabling users to become self-reliant was also limited. Whilst all of the libraries provided ICT rooms and basic training in how to use word-processing programs such as Microsoft Word and Excel as well as how to access the internet, there was a lack of connection between ICT training services and library services. Although librarians occasionally conducted Internet searches, via Google, for users who requested information to complete homework or study assignments, none of the librarians had received any formal skills-training on internet use or Information Literacy training and therefore could not actively transmit those skills to users. Photocopying services were not provided although the user questionnaire indicated that access to a photocopier was in demand in all the 
libraries. None of the libraries performed any outreach activities such as a book-mobile service.

\section{Staff}

In contradiction to Mostert's (1998) criterion of staff providing an "active" service, all librarians indicated they were librarians in name but not by any form of training. They were restricted to a passive service attitude, "we are here to find the books on the shelves when the users request them", and "mostly, we are here to catalogue the books, put them on the shelves, register the name of the user and the books consulted." The librarians indicated that working in the library was a "temporary" measure until they could "find a better job, with a better salary", confirmed by the library directors' admission that librarians "work here to get some work experience for a better job or, to earn a little bit of money while they are studying". None of the library directors had undergone any formal training in librarianship and depended on their own experience as library users or information gleaned from friends or relatives in Portugal who worked in libraries there. Librarians indicated however that they would welcome additional training but had little idea of how to go about obtaining such, while the level of participation of librarians in the process of needs analysis or strategic planning was also limited: "it's the library director who does the work of finding, selecting the books for the library, and we just pass on messages from the users if they want a book that we don't have”. None of the libraries offered any evidence of sustained and regular training or updating of librarians' skills, which confirmed Isaak's $(2003,10-12)$ findings that there is "a lack of professional training of librarians and a lack of recognition of librarianship as a profession".

\section{Cooperation}

The concept of cooperation was defined in two forms by the libraries. For the library directors, cooperation between libraries and other organizations consisted principally of contacts with agencies (non-governmental or philanthropic organizations) outside of Mozambique for procurement of educational textbooks and fiction reading material. Cooperation that occurred within Mozambique, according to the library directors, took place when visiting lay volunteers, mostly from Portugal and Italy, helped to set up the libraries. This consisted of creating contacts with book donors outside of Mozambique, providing basic training to librarians in cataloging and shelf-arrangement and, in the case of the Centro Santa Cruz library, obtaining funds from a Dutch non-governmental organization operating in Nampula to construct the library. From the librarians' perspective, however, cooperation was interpreted as an opportunity for skills training: all surveyed expressed an interest in being in contact with other libraries in order to "exchange our experiences, be more trained in our work" and "know how to attend the users, especially the university students, better". Librarians also wanted to understand better and be more directly involved in the process of acquiring books: "We want to know [...] who the organizations that donate the books are." The perception of needs-analysis was evident at the Naiwanana library when one of the librarians expressed an interest in learning how to analyze the data obtained from the circulation registers: "we register the information about the users, [...] but we don't know how to use that information to manage the library better, so, cooperation is a chance to learn that, to be better trained".

\section{Conclusion}

Qualitative data from interviews with library directors and librarians together with quantitative data from user questionnaires indicate that the four libraries studied function principally as substitute school and university libraries, not as true community libraries according to Mostert's (1998) definition. The two largest user groups consist of a) secondary school students in the $12^{\text {th }}$ grade and b) university students which echoes Hart's (2012) observation that public libraries in Africa cater principally to school learners and indicates the four libraries studied see themselves as a solution to the shortage of educational materials in both school and public libraries. On one hand, the four libraries are successfully meeting one specific recognized need in the communities where they operate and are complying with their stated missions of offering a viable solution to the deficiencies of school and public libraries in the city. However, it would be premature to consider these as true community libraries according to Mostert's (1998) nine-point framework: they have instead have fallen into the same trap as public libraries described in the literature by Du Plessis (2008) by catering only to a restricted group, i. e. those who have reached a certain level of literacy who require access to educational material. Hart's $(2012,43)$ observation that "public libraries [are viewed as being] for the educated, the middle class and students" is, in the 
Mozambican context, confirmed with the qualification that only students, i. e. those in the process of becoming the educated middle class, are the principle users of urban community libraries. It appears that the definition of what constitutes a community library, according to the directors' perspective, diverges from Mostert's model. The library directors consider their libraries to be community libraries as they are physically sited within a 'bairro' community, successfully address the needs of one particular target group of the community, i. e. students, are part of a community center and independent of government control.

The fact that the four libraries have few users in the under 13 years and over 29 years age groups, despite possessing material in their collections for primary school children and non-studying adults, indicates they have not yet been able to formulate strategies and policies that would attract these age groups to their services. The reward system of coaxing users to spend time in the fiction reading room in order to win a free computer training course is well-intentioned however this system does not have, in the researcher's view, a significant positive impact in establishing a true intrinsic reading for pleasure culture as it promotes the idea that reading fiction is only a means to a specific end instead of an end in itself. In contrast, Dent and Yannota $(2005,55)$ identify the practice of reading groups that permit readers to take home reading material to read in their spare time or to their children which permits the development and sustainment of a reading culture not restricted to library premises. The prohibition of home loans at any of the libraries in the study appears to be a such a deeplyingrained library tradition in Mozambique that, interestingly, none of the librarians mentioned as an impediment to promoting a reading culture in their communities, even though the prohibition on home loans reinforces the concept in the community that reading only occurs in the controlled environment of libraries. The policy of restricting reading to the confines of the library has the effect of preventing the creation of Krolak's $(2005,2)$ "literate environments" that is a highly influencing factor in successful literacy acquisition. None of the libraries in the study operated a book-mobile service as this is impeded by the limited transport infra-structure and poorly maintained roads in Mozambique, alongside the concern of book-theft.

The efforts of the Centro Santa Cruz library in setting up a crèche and providing basic literacy lessons for preschool age children are admirable, however still raise the question of what library services could be provided to these children when progressing from primary school through to $12^{\text {th }}$ grade secondary school? Mchombu's (1991) observation that libraries in Africa have suffered a "decoupling from the key target groups" is evidenced here, as the four libraries have only focused on one key target group, i. e. students, rather than recognizing that any given community may have a wider range of key target groups. Admittedly, in the case of another significant target group, the illiterate, the Centro Santa Cruz library attempted to provide services but were unable to continue contributing to the reduction of illiteracy in the community due to fragmented organization by the government which oversees the implementation and funding of literacy training. It is hoped the Mozambican government's proposed 2010-2015 Strategic Plan (Republica de Mocambique 2007) for literacy and adult education will overcome its initial difficulties by involving non-governmental agencies, such as independent community libraries, more successfully in the future.

In addition to impediments faced by the libraries in actively providing services for non-literate and neoliterate members of the community, the four libraries, based on data from interviews with the librarians, exhibit some of the characteristics of Zaaiman's concept of underutilization (Zaaiman, Roux and Rykheer 1988, cited in Mostert 1998, 73). The librarians' lack of participation in planning and decision-making in three of the libraries, as well as the lack of regular training and updating of librarians' skills at all of the four libraries, results in no librarians acquiring skills for working with developing communities. As a result, the librarians suffer from "a lack of knowledge with regard to the real information and skills needs of the community", such as practical information on health, agriculture, legal issues and research skills (Figure 3, How users spend time in the library). In contrast, Dent and Yannota's study (2005) indicated how literacy training, effectively organized, could help provide users with new skills to set up businesses to improve their level of income. In addition, lack of training leaves librarians with no means to inform the community of how they could benefit from library services, confirming Isaak's (2007, 10-12) findings on the absence of a conceptual framework defining the role of public libraries. This study confirms that if there is no conceptual understanding established in the public sphere then there is little probability of untrained librarians in community libraries acquiring a corresponding perception that can be applied in their own libraries. The divergence between librarians' perceptions of the needs of the users, "they only want textbooks", as well as what users would be interested in 
using and doing in the library is illustrated by the results of the user questionnaire, (Table 4, Additional resources and services that users would like the library to provide). Results indicate community members, besides desiring increased access to educational material and electronic resources, are also interested in having access to non-academic books as well as texts on sport and arts, skills-training (e.g. How to read better, How to do research), group activities (Reading Group) and engaging in voluntary work in the library. Data on how users spend their time in the library also reveals agriculture and health to be two categories of information most sought after following educational material. Information regarding health certainly corresponds to Mostert's (1998) definition of "survival information", while interest in information on agriculture indicates users are experiencing the need for material relating to farming which could be met more effectively by the libraries' collections. These are potential service areas that would attract more groups from within the community, involve libraries more closely in the life of their users and potential users, as well as increase their level of impact on the socio-economic development of their communities.

The following actions are suggested so as for these libraries to fulfill the characteristics of a true community library as defined by Mostert:

(a) a greater investment, perhaps by obtaining funding for scholarships from external cooperative links, for the training of librarians so they are able to adopt a more pro-active service attitude to users' needs and also capable of conducting a needs analysis of the community's true informational needs

(b) lobbying by community library directors and/or librarians themselves of higher educational institutions to provide degree-level training in librarianship

(c) an implementation of a library policy, modeled on that of the South African resource centers, which aims to create internal cooperation links for training and knowledge transfer with other community libraries in a given city so the strengths of one community library can be transmitted to others

(d) an adoption of library strategies that address the informational, educational and skills needs of a larger range of target groups (non-literate, neo-literate, jobseekers or small-scale entrepreneurs) in their mission

(e) the acquisition of materials from external and domestic donors that go beyond text-based educational form so collections can successfully address the informational needs of non-student users, including non-Portuguese speaking readers (f) an adoption of the "by the community" viewpoint advocated by Machado (2009) that will result in the library's active engagement and networking with other community organizations, such as non-governmental organizations working in agricultural, health and small-business projects in the city, to the benefit of library users.

If these community libraries are able to undertake the above mentioned changes, then they will be better positioned to function as significant agents of socio-economic and cultural change.

\section{References}

Arts Council, England. 2013. Community Libraries. Learning from Experience: Guiding Principles for Local Authorities. UK: Arts Council England. Accessed October 4, 2014. http://www.arts council.org.uk/advice-and-guidance/browse-advice-and-gui dance/community-libraries-learning-experience-guiding-princi ples-local-authorities.

Cavalcante, L.E., and L.T. Feitosa. 2011. “Bibliotecas Comunitárias: Mediações, Sociabilidades E Cidadania.” Linc Em Revista 7 (1):121-30. Accessed October 5, 2014. http://revista.ibict.br/ liinc/index.php/liinc/article/viewFile/406/269.

Chilundo, A. 2006. "Capacity Building in Higher Education in Mozambique and the Role Played by Cooperating Foreign Agencies: The Case of the World Bank.” UNESCO Forum Occasional Paper Series, Paper No. 12. UNESCO. Accessed October 12, 2014. http://unesdoc.unesco.org/ulis/cgi-bin/ulis.pl?catno= 147819\&set=00543AA07B_1_311\&gp=1\&mode=e\&lin=1\&ll=1.

República de Mocambique Conselho de Ministros. 2011. Estratégia De Alfabetização E Educação De Adultos Em Mocambique, 2010-2015. Maputo: Republica de Mocambique. Accessed June 29, 2014. http://www.mec.gov.mz/DN/DINAEA/Documents/ ESTRAT\%C3\%89GIA\%20DE\%20ALFABETIZA\%C3\%87\%C3\%830 \%20(2010\%20-\%202015)\%20Versao\%20Ass\%20Camacho\% 2015\%2032011.pdf.

Da Costa Santos, M.J.V., A.M. Senna, and M.F. Miranda. 2010. “Biblioteca Comunitária Escritor Lima Barreto: Espaço Para Práticas De Mudancas Socias.” Ponto De Accesso 4 (3):32-44. Accessed 4 October, 2014. https://rigs.ufba.br/index.php/ revistaici/article/view/4687.

Dent, V., and L. Yannota. 2005. "A Rural Community Library in Africa: A Study of Its Use and Users." Libri 55:39-55.

Dent, V.F. 2013. "A Qualitative Study of the Academic, Social and Cultural Factors that Influence Students' Library Use in A Rural Ugandan Village." The International Information \& Library Review 45:37-49.

Du Plessis, J.C. 2008. “"From Food Silos to Community kitchens"Retooling African Libraries." The International Information \& Library Review 40 (1):43-51. Accessed May 5, 2014. http://www.tandfonline.com/doi/abs/10.1080/10572317.2008. 10762761. 
Fundo Bibliográfico De Língua Portuguesa. 2003. Diretório Dos Arquivos, Bibliotecas E Centros De Documentação E Informação Existentes Em Mocambique. Maputo: Fundo Bibliográfico de Língua Portuguesa.

Hanlon, J. 2013. "Mozambique News Reports and Clippings, Minimum Wage and Exchange Rate Supplement" Accessed October 5, 2014. http://www.open.ac.uk/technology/mozambi que/sites/www.open.ac.uk.technology.mozambique/files/ files/Mozambique_216-wage_\%26_exchange_rate_supplement _2013(1).pdf.

Hart, G. 2012. "Moving beyond Outreach: Reflections on Two CaseStudies of Community Library Services in South Africa." South African Journal of Libraries and Information Science, Special Launch Issue. Accessed May 13, 2014. http://sajlis.journals.ac. za/pub/issue/view/9.

Issak, A. 2003. "Panorama Geral Das Unidades De Documentação Em Mocambique." Convergindo. $1^{0}$ Seminario Nacional de Arquivos, Bibliotecas, Centros de Documentação e Museus, 6-8 October 2003. Maputo, edited by W. Amaral. 30-45. Maputo: FundoBibliografico de Lingua Portuguesa. Accessed 29 June 29, 2015. http://www.saber.ac.mz/bitstream/10857/1678/1/ PANORAMA\%20GERAL\%20DAS\%20UNIDADES\% 20DOCUMENTAIS.pdf.

Kretzmann, J., and S. Rans. 2005. The Engaged Library: Chicago Stories of Community Building. Evanston, IL: Urban Libraries Council.

Krolak, L. 2005. The Role of Libraries in the Creation of Literate Environments. Hamburg: UNESCO Institute for Education. Accessed October 13, 2014. http://www.ifla.org/VII/s33/pub/ s33_Krolak\%20L. pdf.

Lodico, M.G., D.T. Spaulding, and K.H. Voegtle. 2006. Research Methods in Education: From Theory to Practice. (1st ed.). San Francisco: John Wiley \& Sons.

Machado, E.C. 2009. "Uma Discussão Acerca Do Conceito De Biblioteca Comunitária." Revista Digital De Biblioteconomia E Ciência Da Informação 7 (1):80-94.

Mchombu, K. 1991. “Which Way African Librarianship?” IFLA Journal 17 (1):26-38.

Miles, M.B., and A.M. Huberman. 1994. Qualitative Data Analysis: An Expanded Sourcebook. (2nd ed.). Thousand Oaks, California: SAGE

Mostert, B.J. 1998. "Community Libraries: The Concept and Its Application - with Reference to a South African Community Library System." International Information and Library Review 30:71-85. Accessed October 4, 2013. http://196.21.83.35/han dle/10530/437.

Republic of Mozambique Ministry of Coordination of Environmental Affairs National Directorate of Territorial Planning Mozambique Report. 2007. Cities without Slums: Analysis of the Situation and Proposal of Intervention Strategies. Maputo: UN-HABITAT.
Accessed October 5, 2014. http://cn.unhabitat.org/content. asp?cid=4399\& catid $=220$ \& typeid $=3 \&$ subMenuld $=0$.

Nassimbeni, M. 1990. "Poverty and Development in South Africa and the Role of Libraries." Journal of Librarianship 22 (3):161-70.

Oliveira, S.M., P.A. Vicente, S. Marcelino, and F.G. Silva. 2010. "Biblioteca Comunitária Saramenha: Espaço Destinado Ao Exercício E Difusão Da Leitura, Cultura E Cidadania.” Anais Da Semana Ciencia E Tecnologia 99-102. Accessed October 12, 2014. http://anaisct.ouropreto.ifmg.edu.br/anais-2010/.

Portal do Governo da Provincia de Nampula. 2015. Informaçôes Gerais. Accessed July 14, 2015. http://www.nampula.gov.mz/ informacao/informacoes-gerais-1/.

Rosenberg, D. 1993. “Imposing Libraries: The Establishment of National Public Library Services in Africa with Particular Reference to Kenya." World Libraries 4 (1). Accessed May 1 , 2014. http://www.worlib.org/vol04no1/rosenberg_v04n1.shtml.

Stilwell, C. 1989. "Community Libraries: A Brief Review of Their Origins and Nature with Particular Reference to South Africa." J. Librarianship 21 (4):260.

Stilwell, C. 1991. "Community Libraries: A Viable Alternative to the Public Library in South Africa?" Progressive Librarian 4:17-27.

Stilwell, C. 1992. "The Resource Centre Forums: Democratic and Alternative Information Networks in South Africa." The International Information \& Library Review 24 (3):213-220.

Stilwell, C. 1994. "Towards Transformation? an Update on the Resource Centre Fora of South Africa." The International Information \& Library Review 26 (4):303-13.

Stilwell, C. 1997. "Democracy and Its Emergence in South African Public Librarianship or Why Public Libraries Plus a Change of Name Don’t Equal Community Libraries." InnovationPietermaritzburg 15: 17-29.

UNDP. 2013. Human Development Reports: Mocambique. Accessed October 5, 2014. http://hdr.undp.org/en/countries/profiles/ MOZ.

UNESCO. 1994. Public Library Manifesto. Accessed June 10, 2014. http://portal.unesco.org/ci/en/ev.php-URL_ID=4638\&URL_ DO=DO_TOPIC\&URL_SECTION=201.html

UN-HABITAT. 2012. Making slums history - global challenge for 2020. Conference report. 26-29 November, 2012. Rabat: ONUHabitat.

Walliman, N. 2005. Your Research Project. (2nd ed.) London: SAGE Witbooi, S. 2007. "Current Developments of Public Libraries in South Africa." In Libraries for the Future: Progress and Development of South African Libraries, edited by T.J.D. Bothma, P. Underwood and P. Ngulube. Pretoria: LIASA. Accessed May 1, 2014. http://www.dissanet.com/jsp/ifla/book.jsp.

World Bank. 2015. "World Development Indicators. Population of Mozambique." Accessed July 14, 2014. http://search.worldbank. org/all?qterm=population + mocambique $+2014 \&$ title=\&filetype . 